\title{
Heterotrophy in the Mediterranean symbiotic coral Cladocora caespitosa: comparison with two other scleractinian species
}

\author{
P. Tremblay ${ }^{1, *}$, A. Peirano ${ }^{2}$, C. Ferrier-Pagès ${ }^{1}$ \\ ${ }^{1}$ Centre Scientifique de Monaco, Avenue St-Martin, 98000 Monaco \\ ${ }^{2}$ ENEA - Marine Environment Research Center, 19100 La Spezia, Italy
}

\begin{abstract}
This experimental study assessed the grazing rates of the Mediterranean symbiotic coral Cladocora caespitosa on the 4 main food sources available in its natural environment: detrital particulate organic matter (DPOM) and pico-, nano-, and microzooplankton. These rates were compared to the rates of 2 other scleractinian symbiotic species, the Mediterranean coral Oculina patagonica and the tropical coral Turbinaria reniformis. Results showed that $C$. caespitosa was the species with the highest grazing rates of pico- and nanoplankton, which contributed to more than half of the carbon supplied by photosynthesis. The daily heterotrophic carbon (C) input from these prey (at in situ concentrations) was $88.3 \pm 22.9,16.9 \pm 8.2$, and $17.6 \pm 4.3 \mu \mathrm{g} \mathrm{C} \mathrm{cm}^{-2} \mathrm{~d}^{-1}$ for C. caespitosa, O. patagonica, and T. reniformis, respectively, corresponding to a percent contribution of heterotrophically acquired C to daily animal respiration (CHAR) of $119.8,28.7$, and $15.9 \%$, respectively. C. caespitosa was also able to derive a significant part of its carbon needs from the grazing of microzooplankton and DPOM. Indeed, considering the in situ concentrations, the daily heterotrophic $\mathrm{C}$ input from microzooplankton and DPOM would be 32.6 and $10.0 \mu \mathrm{g} \mathrm{C} \mathrm{cm} \mathrm{cm}^{-2} \mathrm{~d}^{-1}$, giving a CHAR estimation of 44.2 and $13.6 \%$, respectively. Heterotrophy therefore plays a major role in the energy budget of this temperate species.
\end{abstract}

KEY WORDS: Coral feeding $\cdot$ Heterotrophy $\cdot$ Plankton $\cdot$ Particulate organic matter

\section{INTRODUCTION}

Symbiotic corals acquire carbon and other nutrients via 2 pathways. The autotrophic pathway is provided by the zooxanthellae, the symbiotic dinoflagellates living in the coral tissue, which transfer most of the photosynthetically acquired carbon to the host (Muscatine et al. 1981, McCloskey \& Muscatine 1984). Plankton capture and uptake of dissolved and detritic material constitutes the heterotrophic pathway of acquisition of energy (Sebens et al. 1996, Anthony \& Fabricius 2000, Ferrier-Pagès et al. 2003). In tropical healthy coral species, living mainly in well-lit environments, autotrophy is known to provide up to $100 \%$ of the host's daily metabolic energy requirements and is thought to prevail over heterotrophic feeding (Muscatine et al. 1981, Davies 1984, Falkowski et al. 1984, 1993). Temperate corals, conversely, live in a seasonally changing environment where light and temperature are low during half of the year, reducing the autotrophic input (Muller-Parker \& Davy 2001). It has been therefore suggested that temperate corals may rely more upon heterotrophic feeding to sustain their metabolism compared to tropical organisms (FitzGerald \& Szmant 1988). Heterotrophy was indeed shown to sustain or enhance the growth rate of the temperate corals Oculina arbuscula, Astrangia poculata, and Cladocora caespitosa (Miller 1995, Dimond \& Carrington 2007, Rodolfo-Metalpa et al. 2008), and to increase the rates of respiration of A. danae (Szmant-Froelich \& Pilson 1984). Temperate sea anemones and corals are also able to survive, through heterotrophy, in complete darkness for several weeks (Muller-Parker \& Davy 2001, Hoogenboom et al. 2010). 
Despite this interesting difference in the functioning of tropical and temperate symbioses, the natural diets and grazing rates of temperate symbiotic scleractinian corals has, to our knowledge, never been studied. Existing data concern gorgonian octocorals (Coma et al. 1994, Ribes et al. 2003, Rossi et al. 2004) and sponges (Ribes et al. 1999), most of them asymbiotic. The contribution of auto- and heterotrophy to the carbon budget of temperate scleractinians has also been poorly studied, with experiments using only artificial prey as the food source (Piniak 2002, Hoogenboom et al. 2010). Both studies tested the relationship between heterotrophic consumption and photosynthetic energy. Piniak (2002) demonstrated that feeding in Oculina arbuscula was independent of the symbiotic status. Hoogenboom et al. (2010) showed that the Mediterranean coral Cladocora caespitosa that was fed only Artemia salina nauplii was able to increase its grazing rates when maintained in the dark, to compensate for a decrease in the rates of photosynthesis. In high light condition, nauplii intake was lower, but still significant, and was used to increase the tissue biomass as well as the growth rates (Hoogenboom et al. 2010).

The first aim of the present study was to determine qualitatively and quantitatively the diet of the symbiotic temperate coral Cladocora caespitosa (Linnaeus, 1767), in order to assess the importance of heterotrophy to its carbon budget. C. caespitosa is one of the main endemic Mediterranean coral species, has a large distribution, and can be found in 5 to $40 \mathrm{~m}$ depths, in well-lit or in completely dark and turbid environments (Peirano et al. 1998). How it acquires energy in the low light environments is a question worth examining. The waters of La Spezia, where colonies of C. caespitosa used in the present study were sampled, are particularly rich in particulate and dissolved organic matter (POM and DOM) (Peirano et al. 2005, Cupido et al. 2009), suggesting that heterotrophy can be important in the coral's metabolism. We therefore determined the grazing rates on pico-, nano-, and microzooplankton, as well as the uptake rates of POM in sediment, and data were used to assess the amount of heterotrophic carbon available for the symbiotic association. We also assessed the percent contribution of heterotrophically acquired carbon to daily animal respiration (CHAR) (Grottoli et al. 2006), because respiration constitutes one of the largest fractions of the energy demand of benthic organisms (Davy et al. 1996). The second aim of the present study was to compare C. caespitosa grazing rates with those of 2 other scleractinian coral species, one of Mediterranean origin, Oculina patagonica Angelis, 1908 and one of tropical origin, Turbinaria reniformis Bernard, 1896. O. patagonica is not well distributed in the North Mediterranean Sea, but it constitutes large populations in the south, especially along the Israeli coasts (Zibrowius 1980), suggesting that this coral needs, for its development, higher temperatures and/or higher light levels (and a higher level of autotrophy) than $C$. caespitosa. T. reniformis is a tropical species, thought to mostly rely on autotrophy for its nutritional needs, as with most tropical corals (Muscatine et al. 1981). The 3 coral species investigated should therefore represent a gradient of heterotrophy and should differ in their planktonic grazing rates.

\section{MATERIALS AND METHODS}

Biological material. The present study was conducted with 2 Mediterranean scleractinian species, Cladocora caespitosa (Faviidae) and Oculina patagonica (Oculinidae), and 1 tropical species, Turbinaria reniformis (Dendrophylliidae). Six colonies (ca. $7 \mathrm{~cm}$ in diameter) of C. caespitosa were randomly collected in the Bay of Fiascherino in the Gulf of La Spezia, Italy $\left(44^{\circ} 03^{\prime} \mathrm{N}, 9^{\circ} 55^{\prime} \mathrm{E}\right)$ at 7 to $10 \mathrm{~m}$ depth. In this area, the species is very abundant and well distributed. It thrives in very turbid waters and under low light conditions most of the year (10 to $100 \mu \mathrm{mol}$ photons $\mathrm{m}^{-2} \mathrm{~s}^{-1}$ ) depending on the season (Peirano et al. 1999, 2005), except in summer, when turbidity is reduced, allowing more light to reach the corals (ca. $250 \mu$ mol photons $\mathrm{m}^{-2} \mathrm{~s}^{-1}$; Peirano 2007). Colonies were cleaned of epiphytes and each divided into nubbins of 4 to 5 polyps ( $\mathrm{n}=24$ nubbins in total). Eighteen small samples of $O$. patagonica were also collected at Albissola, $100 \mathrm{~km}$ from La Spezia (Gulf of Genoa, 44 $17^{\prime} \mathrm{N}, 8^{\circ} 30^{\prime} \mathrm{E}$ ) at $5 \mathrm{~m}$ depth. At this location, O. patagonica covers several $\mathrm{m}^{2}$ of surface area and grows on a vertical cliff facing north, which prevents exposure to direct sunlight. Finally, 6 colonies of $T$. reniformis were collected in the Red Sea, near Djibouti, at $10 \mathrm{~m}$ depth. Eighteen nubbins were prepared by cutting portions of the mother colonies with a bone cutter. After collection, corals were maintained for some time in aquaria under controlled conditions (see 'Experimental design' below) until they recovered.

Experimental design. Once prepared, nubbins of the 2 Mediterranean species were split into two 201 tanks ( $\mathrm{n}=12$ for Cladocora caespitosa and $\mathrm{n}=9$ for Oculina patagonica in each tank). These tanks were continuously supplied with seawater pumped from $50 \mathrm{~m}$ depth in front of the laboratory (renewal rate: $10 \mathrm{l} \mathrm{h}^{-1}$ ). This seawater contained low levels of inorganic and organic nutrients (Ferrier-Pagès et al. 1998). Corals were maintained at a temperature of $18 \pm 0.5^{\circ} \mathrm{C}$ and at a light level of $\sim 50 \mu \mathrm{mol}$ photons $\mathrm{m}^{-2} \mathrm{~s}^{-1}(12 \mathrm{~h}$ light:12 h dark photoperiod), which are the conditions occurring in spring and autumn in the Mediterranean Sea at 8 to 
$10 \mathrm{~m}$ depth where the corals live. Nubbins of Turbinaria reniformis were maintained in 2 other 201 tanks ( $\mathrm{n}=9 \operatorname{tank}^{-1}$ ) with the same source of continuously flowing seawater, in this case at $25.0 \pm 0.5^{\circ} \mathrm{C}$ and $\sim 120 \mu \mathrm{mol}$ photons $\mathrm{m}^{-2} \mathrm{~s}^{-1}(12 \mathrm{~h}$ light:12 h dark photoperiod), which are conditions more typical for a tropical species. Light was maintained at a low level to favor heterotrophy, and for each coral species, it was set up to have approximately equivalent rates of photosynthesis (see 'Results'), and therefore an equivalent autotrophic input. Temperature was kept constant using heaters connected to electronic controllers. Light was provided by a 400 Watt HQI metal halide lamp. Nubbins were not fed, except during the feeding experiments.

Feeding experiments. Feeding experiments were performed with 3 types of food for Cladocora caespitosa: pico- and nanoplankton (heterotrophic bacteria [BA], cyanobacteria [CYA], autotrophic pico- and nanoflagellates [APF and ANF], heterotrophic picoand nanoflagellates [HPF and HNF]), microzooplankton (Artemia salina nauplii), and detrital POM (DPOM). Only the first 2 types of food were used for comparison with Oculina patagonica and Turbinaria reniformis, because these coral species do not encounter high levels of detrital organic matter in their normal environments. Grazing was assessed using clearance rates, as used in studies on gorgonians (Ribes et al. 1998, 2003), sponges (Ribes et al. 1999), and corals (Houlbrèque et al. 2004). Analysis of the stomach contents of the polyps cannot be used because the minute prey organisms degrade rapidly. Incubations were therefore performed in $900 \mathrm{ml}$ Plexiglas flow chambers (described in Levy et al. 2001, Houlbrèque et al. 2004, Picciano \& Ferrier-Pagès 2007), incubated in a water bath maintained at a constant temperature (either 18 or $25^{\circ} \mathrm{C}$ ). Corals occupied only ca. 20 to $50 \mathrm{ml}$ of the total volume. Water was circulated by a motor-driven propeller with a defined rotational speed, equal to $1.7 \mathrm{~cm} \mathrm{~s}^{-1}$. Flow velocity was measured by following the movement of brightly illuminated plastic beads added to the seawater. The bead movements were recorded with a video camera and the flow velocity was calculated as described by Trager et al. (1990).

Pico- and nanoplankton grazing rates: Experiments were performed in autumn (September and October 2009). Four chambers were filled with surface seawater collected each morning in front of the laboratory and concentrated on a $1 \mu \mathrm{m}$ filter using a reversefiltration apparatus to avoid cell breakage and lysis (Sheldon \& Rassoulzadegan 1987). Three chambers received a coral nubbin, while 1 chamber was kept as a control (without coral). For each coral species, a total of 9 incubations (with nubbins from all the different colonies) were carried out over $6 \mathrm{~h}$ in the dark. The incubation time needed to monitor a change in prey concentration was determined in preliminary experiments. The incubation started when polyps were expanded (controlled using a red light for few seconds). Control chambers (without corals) allowed us to estimate the autogenic change in pico- and nanoplankton concentrations resulting from internal grazing (within the microbial loop), natural death, or growth. This change is independent of coral predation and has to be taken into account in the grazing-rate equations. For all incubations, $10 \mathrm{ml}$ seawater samples were collected in triplicate from each chamber at the beginning and end of the incubation (after having thoroughly mixed the seawater) in order to determine pico- and nanoplankton concentrations. They were fixed with formaldehyde $(0.5 \%$ final concentration $)$, stained with DAPI (Porter \& Feig 1980), filtered onto $0.2 \mu \mathrm{m}$ black Isopore membrane filters $25 \mathrm{~mm}$ (GTBP02500, Millipore) and frozen at $-20^{\circ} \mathrm{C}$ until further analysis. The filters were used for the visual quantification of picoand nanoplankton on an epifluorescence microscope according to Ferrier-Pagès \& Gattuso (1998).

Grazing rates were calculated according to the equations of Ribes et al. (1998), derived from the equations of Frost (1972), which take into account the growth or the lysis of the prey during the incubations. All equations are also fully described in Houlbrèque et al. (2004) and Picciano \& Ferrier-Pagès (2007). Grazing rates were either expressed as number of prey, or as $\mu \mathrm{g}$ carbon and nitrogen ingested. For this purpose, carbon and nitrogen contents of prey items were estimated from literature conversion factors used in other studies on anthozoan feeding (Houlbrèque et al. 2004, Picciano \& Ferrier-Pagès 2007). Three normalizations were performed: per polyp, per unit protein content, and per unit skeletal surface area. While polyp (predation unit) is the most often used parameter in coral feeding studies (Sebens et al. 1996, Ribes et al. 1998, Piniak 2002), skeletal surface area (considered the exchange surface) can be a good normalization unit in the present experiment because of the different polyp sizes of the species investigated (Table 1). Protein (total tissue biomass) normalization allows additional comparison between species.

Skeletal surface area was determined using the aluminum foil technique (Marsh 1970) for Oculina patagonica and Turbinaria reniformis, which have small polyps and tissue between polyps, and mean polyp surface area (Rodolfo-Metalpa et al. 2006) for Cladocora caespitosa, which has big independent polyps. The total number of polyps was determined for each colony. Protein content was measured using the BC Assay Kit (Interchim) (Smith et al. 1985), after extraction in $1 \mathrm{~N} \mathrm{NaOH}$ at $90^{\circ} \mathrm{C}$ for $30 \mathrm{~min}$. The standard 
Table 1. Cladocora caespitosa, Oculina patagonica, Turbinaria reniformis. Characteristics of the coral species used for the grazing and photosynthesis rate measurements. Data are mean \pm SE. zoox.: zooxanthellae

\begin{tabular}{|c|c|c|c|c|c|c|c|}
\hline \multirow{2}{*}{ Species } & \multicolumn{2}{|c|}{${ }_{-}$Polyp } & \multicolumn{2}{|c|}{ Protein concentration } & \multicolumn{2}{|c|}{ Chl $a+C_{2}$ concentration } & \multirow{2}{*}{$\begin{array}{l}\text { Zooxanthellae } \\
\left.\qquad \times 10^{6} \mathrm{~cm}^{-2}\right)\end{array}$} \\
\hline & Size $(\mathrm{mm})$ & Density $\left(\mathrm{cm}^{-2}\right)$ & $\left(\mathrm{mg}\right.$ polyp $\left.{ }^{-1}\right)$ & $\left(\mathrm{mg} \mathrm{cm}^{-2}\right)$ & $\left(\mu \mathrm{g} \mathrm{cm}{ }^{-2}\right)$ & $\left(\times 10^{-6} \mu \mathrm{g}\right.$ zoox..$\left.^{-1}\right)$ & \\
\hline C. caespitosa & $3.93 \pm 0.10$ & $2.07 \pm 0.12$ & $2.09 \pm 0.15$ & $4.01 \pm 0.22$ & $10.84 \pm 0.83$ & $5.13 \pm 0.51$ & $2.16 \pm 0.27$ \\
\hline O. patagonica & $2.97 \pm 0.05$ & $4.24 \pm 0.16$ & $0.51 \pm 0.03$ & $2.13 \pm 0.09$ & $6.03 \pm 0.38$ & $1.58 \pm 0.58$ & $3.84 \pm 0.32$ \\
\hline T. reniformis & $2.47 \pm 0.04$ & $4.42 \pm 0.13$ & $1.12 \pm 0.06$ & $4.94 \pm 0.28$ & $4.11 \pm 0.22$ & $6.10 \pm 0.61$ & $0.69 \pm 0.10$ \\
\hline Sample size (n) & 66 & $18-24$ & $15-18$ & $15-18$ & 6 & 6 & 6 \\
\hline
\end{tabular}

curve was established using bovine serum albumin and absorbance was measured with a Xenius spectrofluorometer (Safas).

In parallel to the grazing rate experiments, pico- and nanoplankton concentrations were also measured in situ, near colonies of Cladocora caespitosa. Samples of seawater were collected in triplicate in September 2009 at 2 locations in the Gulf of La Spezia, at $1 \mathrm{~m}$ above the coral patches, and were treated and counted as described bove, using DAPI staining and epifluorescence microscopy.

Microzooplankton grazing rates: For the determination of the microzooplankton grazing rates, the chambers ( 3 chambers containing 1 coral nubbin each and 1 control) were filled with $0.45 \mu \mathrm{m}$-filtered seawater (FSW). After polyps opened, ca. 2000 Artemia salina nauplii were added to each chamber (concentration of $1671 \pm$ 394 nauplii $^{-1}$ ). A total of 11 incubations were carried out for $120 \mathrm{~min}$ in the dark for Cladocora caespitosa, and 6 incubations for Oculina patagonica and Turbinaria reniformis. Triplicate $10 \mathrm{ml}$ seawater samples were taken at 30 min intervals $\left(t_{0}, t_{30}, t_{60}, t_{90}\right.$, and $\left.t_{120}\right)$ and $A$. salina nauplii counted using a binocular and replaced in the chambers to avoid any artificial concentration decrease. Therefore, food was always kept at a high enough concentration to saturate coral feeding. For C. caespitosa only, grazing rates were also measured using different $A$. salina nauplii concentrations in seawater: ca. 500, 900, 1300, 2400, and 3200 nauplii $\mathrm{l}^{-1}$. Regressing grazing rates versus nauplii concentrations allowed us to estimate the grazing rates of the natural in situ plankton concentration and assess the in situ heterotrophic carbon input for C. caespitosa.

Grazing rates were calculated as the decrease in nauplii concentration for a given amount of time. They were also expressed as $\mu \mathrm{g}$ of carbon or $\mu \mathrm{g}$ nitrogen ingested. For this purpose, ca. 2000 nauplii were filtered on pre-combusted GF/F glass microfiber filters $25 \mathrm{~mm}$ (1825-025, Whatman) and carbon and nitrogen contents were determined using a CHN analyzer as described below ('DPOM grazing rates'). The nauplii contained $1.24 \pm 0.5 \mu \mathrm{g} \mathrm{C}$ nauplii ${ }^{-1}$ and $0.25 \pm 0.01 \mu \mathrm{g} \mathrm{N}$ nauplii ${ }^{-1}$. The natural concentration of microzooplankton was also determined in situ, near Cladocora caespi- tosa colonies, using plankton nets. Copepods and copepodites were counted under a binocular microscope.

DPOM grazing rates: To evaluate the grazing on DPOM contained in the sediment surrounding Cladocora caespitosa beds, sediment samples were collected within the coral patches at $11 \mathrm{~m}$ depth in the Gulf of La Spezia. The sediment was then successively filtered onto $180 \mu \mathrm{m}$ and $40 \mu \mathrm{m}$ filters to discard sandgrains and pieces of coral skeleton and to keep most of the organic matter fraction. This fraction was freeze-dried and its carbon and nitrogen content per mg dry weight of powder determined using a Perkin Elmer 2400 Series II CHNS/O Elemental Analyzer. The calibration was conducted with standards (K-factor) of glycine $(32.00 \%$ of carbon and $18.66 \%$ of nitrogen) and the carbon and nitrogen value of the filters (blank) was also determined. The sediment contained $12.9 \pm 1.6 \mu \mathrm{g} \mathrm{C} \mathrm{mg}^{-1}$ and $1.7 \pm$ $0.2 \mu \mathrm{g} \mathrm{N} \mathrm{mg}^{-1}$.

Three chambers, all containing a coral nubbin, were filled with FSW. When the polyps opened, a known amount of powder was added into 2 chambers, the last one being kept as a control (for release of POM by the corals). The experiment was repeated 3 times in the dark, with 1 nubbin from each mother colony each time $(n=6)$. At the end of the incubation, the entire incubation medium of each chamber was filtered onto pre-combusted GF/F glass microfiber filters 25 mm (1825-025, Whatman). The carbonate in the samples was eliminated with $10 \% \mathrm{HCl}$ and the filter was rinsed with distilled water, and dried at $60^{\circ} \mathrm{C}$. The remaining DPOM carbon and nitrogen was assessed as described above using a CHNS/O Elemental Autoanalyser.

Grazing rate of detrital particulate carbon $\left(I_{C}\right)$ by Cladocora caespitosa was calculated according to the following equation:

$$
\text { IC }=\mu g \text { C added }-(\mu g \mathrm{C} \text { remaining }-\mu \mathrm{g} \text { C excreted })
$$

where ' $\mu \mathrm{g} \mathrm{C}$ added' is the total amount of carbon added at the beginning of the incubation; ' $\mu \mathrm{g} \mathrm{C}$ remaining' is the amount of carbon remaining in the incubation medium at the end of incubation, and ' $\mu \mathrm{g} \mathrm{C}$ excreted' is the amount of carbon excreted (in the form of mucus), by the coral colony in the control chamber during the incubation time. This carbon excreted was 
calculated by subtracting the amount of carbon in the FSW blank from the amount of carbon in the control chamber at the end of the incubation time. The same calculations were performed for the grazing rate of detrital particulate nitrogen.

Rates of photosynthesis. The rates of respiration and photosynthesis of 6 nubbins per species (with 1 nubbin from each mother colony) were assessed according to the methods of Hoogenboom et al. (2010), except that temperature and irradiance in the chambers was set at $18^{\circ} \mathrm{C}$ and $50 \mu \mathrm{mol}$ photons $\mathrm{m}^{-2} \mathrm{~s}^{-1}$ for the temperate species and to $25^{\circ} \mathrm{C}$ and $120 \mu \mathrm{mol}$ photons $\mathrm{m}^{-2} \mathrm{~s}^{-1}$ for the tropical species. Rates of gross photosynthesis $\left(P_{\mathrm{g}}\right)$ were calculated by adding the rates of respiration $(R)$ in the dark to the rates of net photosynthesis $\left(P_{\mathrm{n}}\right)$. Samples were then frozen for zooxanthellae and chl $a+c_{2}$ concentrations. Data were normalized to the skeletal surface area in $\mathrm{cm}^{2}$ ( $\mu \mathrm{mol} \mathrm{O}_{2} \mathrm{~cm}^{-2} \mathrm{~h}^{-1}$ ) and to the chlorophyll content $\left(\mu \mathrm{mol} \mathrm{O} \mathrm{O}_{2} \mu \mathrm{g} \mathrm{chl} a+c_{2}^{-1} \mathrm{~h}^{-1}\right)$. Zooxanthellae density and chlorophyll concentrations were determined according to the methods of Rodolfo-Metalpa et al. (2006).

Daily carbon acquisition. Cladocora caespitosa: Once we measured the photosynthetic and grazing rates, we compared total daily carbon acquisition via autotrophy and heterotrophy for C. caespitosa, when maintained under a mean light level of $50 \mu \mathrm{mol}$ photons $\mathrm{m}^{-2} \mathrm{~s}^{-1}$. Total daily acquisition of carbon through autotrophy $\left(P_{\mathrm{C}}\right)$ was calculated using $P_{\mathrm{g}}$ measured at $50 \mu \mathrm{mol}$ photons $\mathrm{m}^{-2} \mathrm{~s}^{-1}$, considering a $12 \mathrm{~h}$ daylight period. Oxygen fluxes were converted to carbon equivalents based on molar weights, as $P_{\mathrm{C}}=\mu \mathrm{mol} \mathrm{O}_{2}$ produced $\times 12 / \mathrm{PQ}$, and the daily loss of carbon through respiration $\left(R_{\mathrm{C}}\right)=\mu \mathrm{mol}$ $\mathrm{O}_{2}$ consumed $\times 12 \times \mathrm{RQ}$ (Anthony \& Fabricius 2000), where $P Q$ and $R Q$ are photosynthetic and respiratory quotients equal to 1.1 and 0.8 respectively (Muscatine et al. 1981). Potential daily carbon acquisition from heterotrophy $\left(H_{C}\right)$ was calculated based on the measured grazing rates on pico- and nanoplankton, microzooplankton, and DPOM, considering their in situ concentrations and their relative carbon content. An unknown variable is the amount of time spent on feeding every day by $C$. caespitosa. We therefore assumed a continuous feeding on pico- and nanoplankton, because these particles are present at $>10^{5}$ cells ml ${ }^{-1}$ seawater, and only $1 \mathrm{~h}$ of active feeding on microzooplankton and DPOM, which are less abundant than pico- and nanoplankton. This will give the minimal heterotrophic input for this species. We calculated the CHAR (Grottoli et al. 2006) under the above conditions.

Oculina patagonica and Turbinaria reniformis: For these 2 species, the aim was not to make a daily carbon budget, but rather compare their grazing rates and heterotrophic income with that of Cladocora caespitosa. We therefore assumed that in situ pico- and nanoplankton cells were at approximately the same con- centrations as in the Mediterranean or reef waters surrounding these corals (Ferrier-Pagès \& Gattuso 1998). For microzooplankton, we assumed the same in situ concentration for Oculina patagonica as those measured near C. caespitosa colonies, since these corals were sampled in the same area. For Turbinaria reniformis, it is well known that microzooplankton concentrations are low in reef waters, except during the night, when zooplankton migrates from deep waters to near the corals (Yahel et al. 2005). We therefore used a concentration of 2 organisms $1^{-1}$ (Yahel et al. 2005). All parameters were estimated as described above for $C$. caespitosa, except that the autotrophic carbon acquisition was calculated from the rates of photosynthesis at 50 and $120 \mu \mathrm{mol}$ photons $\mathrm{m}^{-2} \mathrm{~s}^{-1}$ for O. patagonica and T. reniformis, respectively.

Statistical analysis. All grazing rates were expressed as mean \pm SE. Data were checked for normality using a Kolmogorov-Smirnov test with the Lilliefors correction. When normality was not fulfilled, a data transformation was performed or a nonparametric test was used. Significant differences in pico- and nanoplankton concentrations between the in situ and the experimental samples were tested using a 2 -sample $t$-test with $\mathrm{df}=17$. The difference in grazing rates between coral species was tested using a nonparametric Kruskal-Wallis test with $\mathrm{df}=2$. These analyses were followed by a nonparametric post hoc test (Conover-Inman test) when significant. Differences between factors were considered significant for $\mathrm{p}<0.05$. Statistics were performed using Systat 13 .

\section{RESULTS}

\section{Rate of photosynthesis}

Rates of gross photosynthesis normalized to the skeletal surface area were equivalent for Cladocora caespitosa under a light level of $50 \mu \mathrm{mol}$ photons $\mathrm{m}^{-2} \mathrm{~s}^{-1}$ and Turbinaria reniformis under a light level of $120 \mu \mathrm{mol}$ photons $\mathrm{m}^{-2} \mathrm{~s}^{-1}$ (Table 2). Oculina patagonica had slightly lower rates (Table 2). When normalized per unit of chlorophyll content, T. reniformis had higher photosynthesis rates than $O$. patagonica and C. caespitosa (Table 2), showing that its associated zooxanthellae had a better and higher photosynthetic capacity. In terms of carbon, gross photosynthesis $\left(P_{\mathrm{C}}\right)$ supplied $143.2 \pm 32.9$ and $98.9 \pm 2.9 \mu \mathrm{g} \mathrm{C} \mathrm{cm} \mathrm{cm}^{-2} \mathrm{~d}^{-1}$ to C. caespitosa and $O$. patagonica, respectively, when maintained under a light level of $50 \mu \mathrm{mol}$ photons $\mathrm{m}^{-2} \mathrm{~s}^{-1}$, and $133.1 \pm 16.9 \mu \mathrm{g} \mathrm{C}$ $\mathrm{cm}^{-2} \mathrm{~d}^{-1}$ to $T$. reniformis when maintained under a light level of $120 \mu \mathrm{mol}$ photons $\mathrm{m}^{-2} \mathrm{~s}^{-1}$. The corresponding respiration $\left(R_{\mathrm{C}}\right)$ consumed $73.7 \pm 4.3,59.0 \pm 5.2$, and $111.1 \pm 12.9 \mu \mathrm{g} \mathrm{C} \mathrm{cm}^{-2} \mathrm{~d}^{-1}$ for C. caespitosa, O. patagonica, and T. reniformis respectively (Table 2). 
Table 2. Cladocora caespitosa, Oculina patagonica, Turbinaria veniformis. Rates of gross photosynthesis $\left(P_{\mathrm{g}}\right)$ and respiration $(R)$ normalized either per skeletal surface area $\left(\mu \mathrm{mol} \mathrm{O} \mathrm{Cm}^{-2} \mathrm{~h}^{-1}\right)$, or per unit chlorophyll $\left(\mu \mathrm{mol} \mathrm{O} 2\left(\mu \mathrm{g} \text { chl } a+C_{2}\right)^{-1} \mathrm{~h}^{-1}\right)$. Photosynthesis and respiration was also expressed as carbon equivalents $\left(P_{\mathrm{C}}\right.$ and $\left.R_{\mathrm{C}}\right)$ normalized per skeletal surface area $\left(\mu \mathrm{C} \mathrm{C} \mathrm{cm}^{-2} \mathrm{~d}^{-1}\right)$. Data are mean $\pm \mathrm{SE}$ for 6 nubbins of each species

\begin{tabular}{|c|c|c|c|c|c|c|}
\hline Species & $\mu \mathrm{mol} \mathrm{O} \mathrm{Cm}^{-2} \mathrm{~h}^{-1}$ & $\begin{array}{c}P_{\mathrm{g}} \\
\mu \mathrm{mol} \mathrm{O}_{2} \\
\left(\mu \mathrm{g} \mathrm{chl} a+C_{2}\right)^{-1} \mathrm{~h}^{-1}\end{array}$ & $\mu \mathrm{g} \mathrm{C} \mathrm{cm}{ }^{-2} \mathrm{~d}^{-1}$ & $\mu \mathrm{mol} \mathrm{O} \mathrm{Cm}^{-2} \mathrm{~h}^{-1}$ & 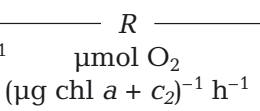 & $\mu \mathrm{g} \mathrm{C} \mathrm{cm}{ }^{-2} \mathrm{~d}^{-1}$ \\
\hline C. caespitosa & $1.094 \pm 0.251$ & $0.099 \pm 0.015$ & $143.2 \pm 32.9$ & $0.320 \pm 0.019$ & $0.030 \pm 0.003$ & $73.7 \pm 4.3$ \\
\hline O. patagonica & $0.755 \pm 0.022$ & $0.110 \pm 0.010$ & $98.9 \pm 2.9$ & $0.256 \pm 0.023$ & $0.043 \pm 0.005$ & $59.0 \pm 5.2$ \\
\hline T. reniformis & $1.017 \pm 0.129$ & $0.234 \pm 0.024$ & $133.1 \pm 16.9$ & $0.482 \pm 0.056$ & $0.111 \pm 0.012$ & $111.1 \pm 12.9$ \\
\hline
\end{tabular}

\section{Feeding experiments}

Pico- and nanoplankton

The mean pico- and nanoplankton concentrations used in the experiments were in the same range as those measured in situ around the colonies of Cladocora caespitosa (Fig. 1). CYA concentrations were

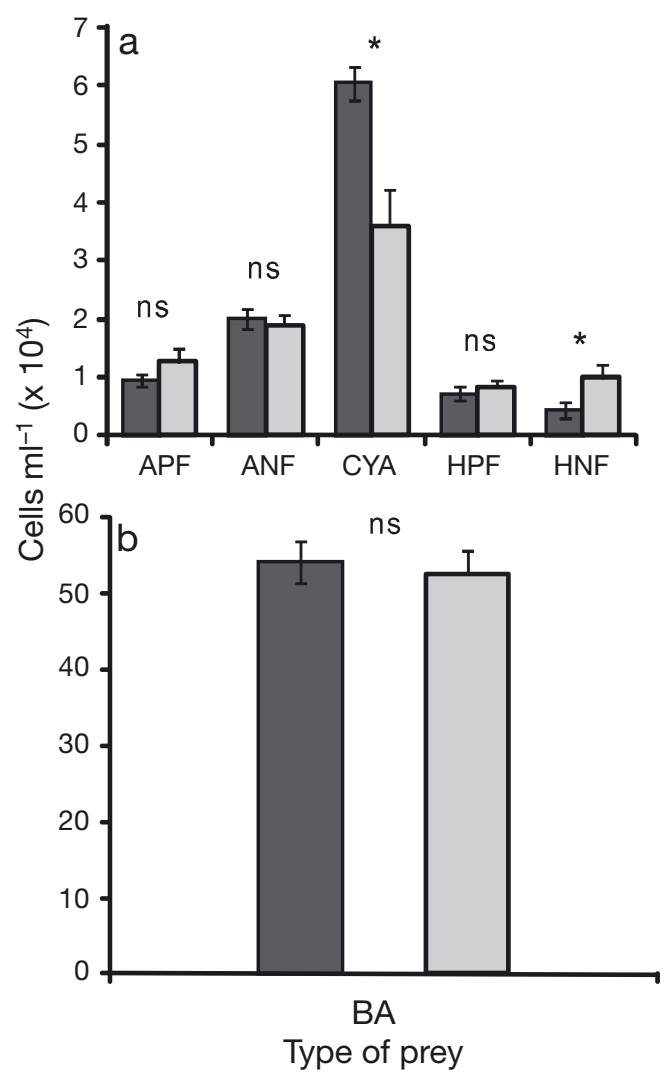

Fig. 1. Pico- and nanoplankton concentrations (means $\pm \mathrm{SE}$ ) measured in situ around Cladocora caespitosa colonies (dark grey bar) $(\mathrm{n}=10)$ and during the experiments (light grey bar) $(\mathrm{n}=9)$. (a) APF: autotrophic picoflagellates; ANF: autotrophic nanoflagellates; CYA: cyanobacteria; HPF: heterotrophic picoflagellates; HNF: heterotrophic nanoflagellates. (b) BA: bacteria. For the 2-sample $t$-test: ${ }^{*} \mathrm{p}<0.05$ and ns: not significant slightly higher in situ $\left(6.1 \times 10^{4} \pm 0.3 \times 10^{4}\right.$ versus $4.1 \times$ $10^{4} \pm 1.1 \times 10^{4}$ cells $\mathrm{ml}^{-1}$ ) while HNF concentrations were lower $\left(0.4 \times 10^{4} \pm 0.1 \times 10^{4}\right.$ versus $1.3 \times 10^{4} \pm 0.4 \times$ $10^{4}$ cells $\mathrm{ml}^{-1}$ ). During the incubations, the different corals differently caught the pico- and nanoplankton cells (Fig. 2). For example, APF were grazed by Oculina patagonica in only 3 incubations out of 9, suggesting that some selection had occurred. HNF were the only type of prey preferentially grazed by the 3 coral species (ingested in $>7$ incubations).

Cladocora caespitosa was the species with the highest grazing rates (Fig. 3; Kruskal-Wallis test: $\mathrm{p}<0.05$ ) of ANF, HNF, CYA, and BA compared to the 2 other species (Conover-Inman test: $p<0.05$ ) for the 3 normalizations considered. There was no significant difference between the grazing rates (normalized per surface area or per polyp) of the 2 other species, Oculina patagonica and Turbinaria reniformis (Conover-Inman test: $p>0.05)$. In terms of number of prey ingested (Fig. 3), BA contributed $73.5 \pm 14.9$ to $86.6 \pm 2.4 \%$ of the cells ingested, followed by CYA $(9.4 \pm 4.7$ to $33.7 \pm$ $12.3 \%$ ), and flagellates (APF: $5.4 \pm 3.3$ to $22.0 \pm 8.7 \%$;

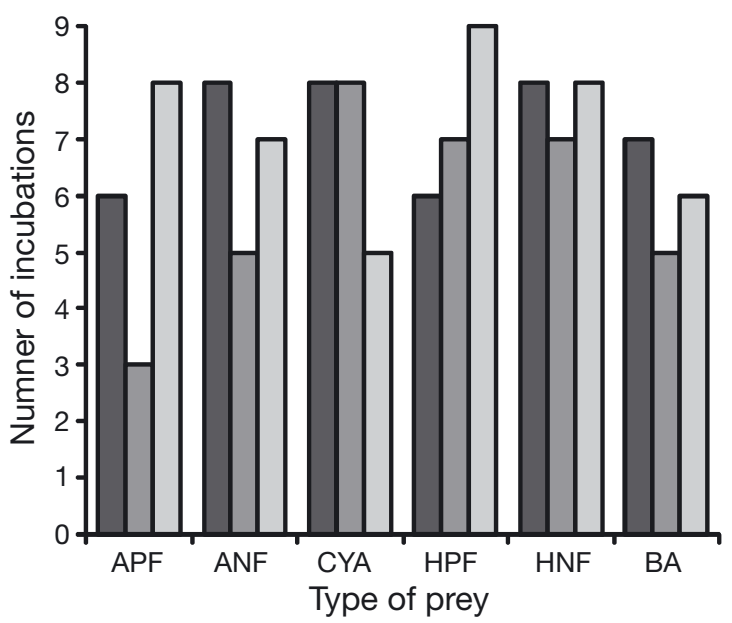

Fig. 2. Number of incubations (out of a total of 9) in which a decrease in prey concentration was detected for Cladocora caespitosa (dark grey bar), Oculina patagonica (grey bar), and Turbinaria reniformis (light grey bar). See Fig. 1 legend for abbreviations 

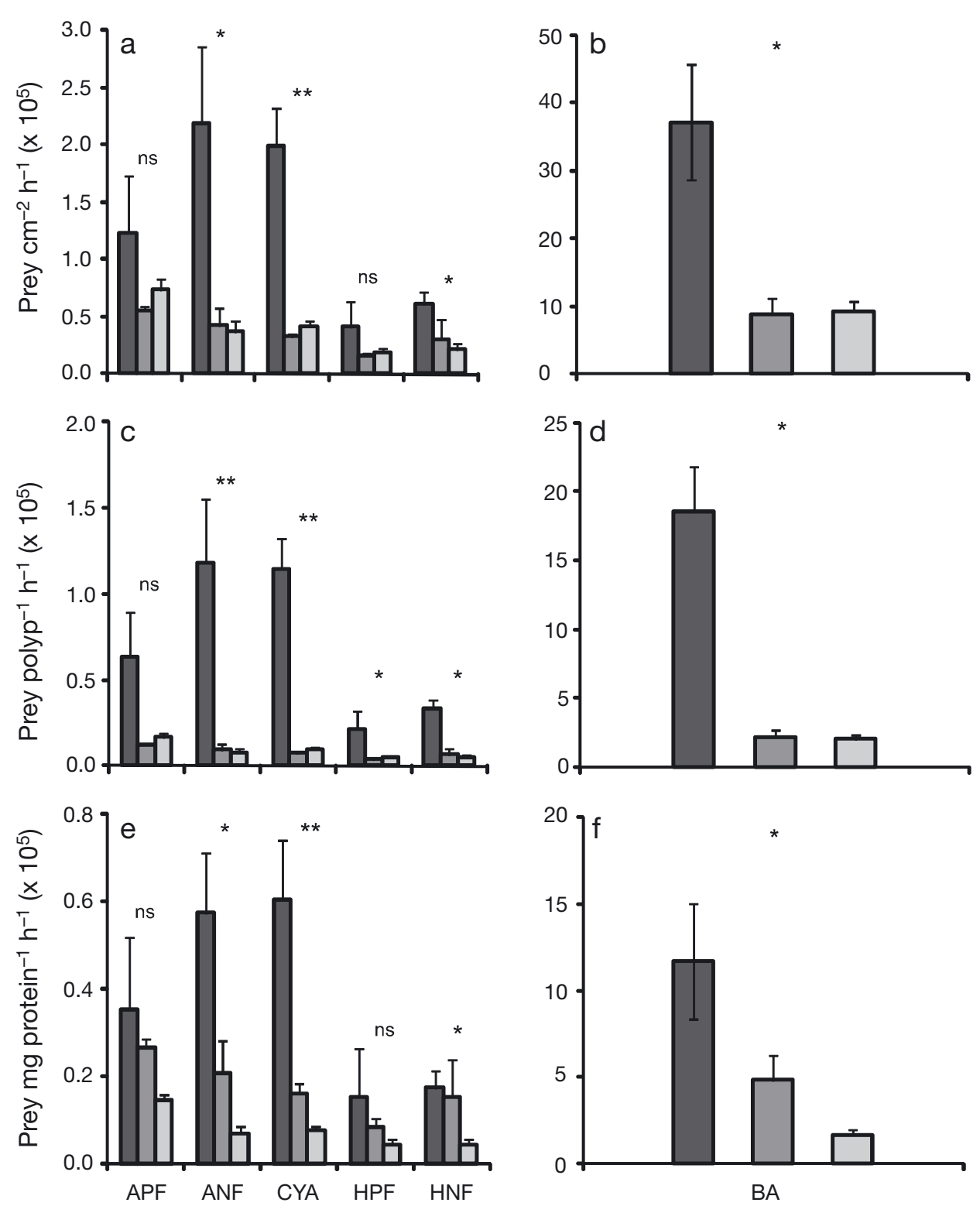

Type of prey

Fig. 3. Grazing rates expressed as number of prey ingested per hour and $(\mathrm{a}, \mathrm{b})$ per $\mathrm{cm}^{2},(\mathrm{c}, \mathrm{d})$ per polyp, and $(\mathrm{e}, \mathrm{f})$ per mg protein for Cladocora caespitosa (dark grey bar), Oculina patagonica (grey bar), and Turbinaria reniformis (light grey bar) according to the type of prey (means $\pm \mathrm{SE}, \mathrm{n}=9$ ). See Fig. 1 legend for abbreviations. For the Kruskal-Wallis test: ${ }^{*} \mathrm{p}<0.05,{ }^{* *} \mathrm{p}<0.001$, and ns: not significant

HPF: $2.0 \pm 0.5$ to $18.7 \pm 6.5 \%$; ANF: $9.6 \pm 7.3$ to $12.0 \pm$ $6.1 \%$; and HNF: $2.5 \pm 0.8$ to $8.0 \pm 3.6 \%$ ). In terms of carbon and nitrogen (Fig. 4), nanoflagellates however represented the most important contribution to the 3 coral species. ANF ranged from $49.5 \pm 7.4$ to $77.7 \pm$ $5.2 \%$ of the total carbon input and from $47.2 \pm 7.8 \%$ to $74.8 \pm 5.0 \%$ of the total nitrogen input. HNF represented from $31.7 \pm 10.1$ to $57.6 \pm 8.4 \%$ of the total carbon input and from $30.3 \pm 9.5$ to $56.9 \pm 8.3 \%$ of the total nitrogen.
The total amount of pico- and nanoplankton captured by Cladocora caespitosa was on average 3 to 5 times higher (Table 3; Kruskal-Wallis test: p < 0.05) than the amount captured by the other 2 species, independently of the normalization used (Conover-Inman test: $\mathrm{p}<0.05)$. Oculina patagonica and Turbinaria reniformis, however, presented equivalent grazing rates (Conover- Inman test: $\mathrm{p}>0.05$ ). Assuming that in situ, pico- and nanoplankton are continuously ingested by the corals, and occur at about the same concentrations 

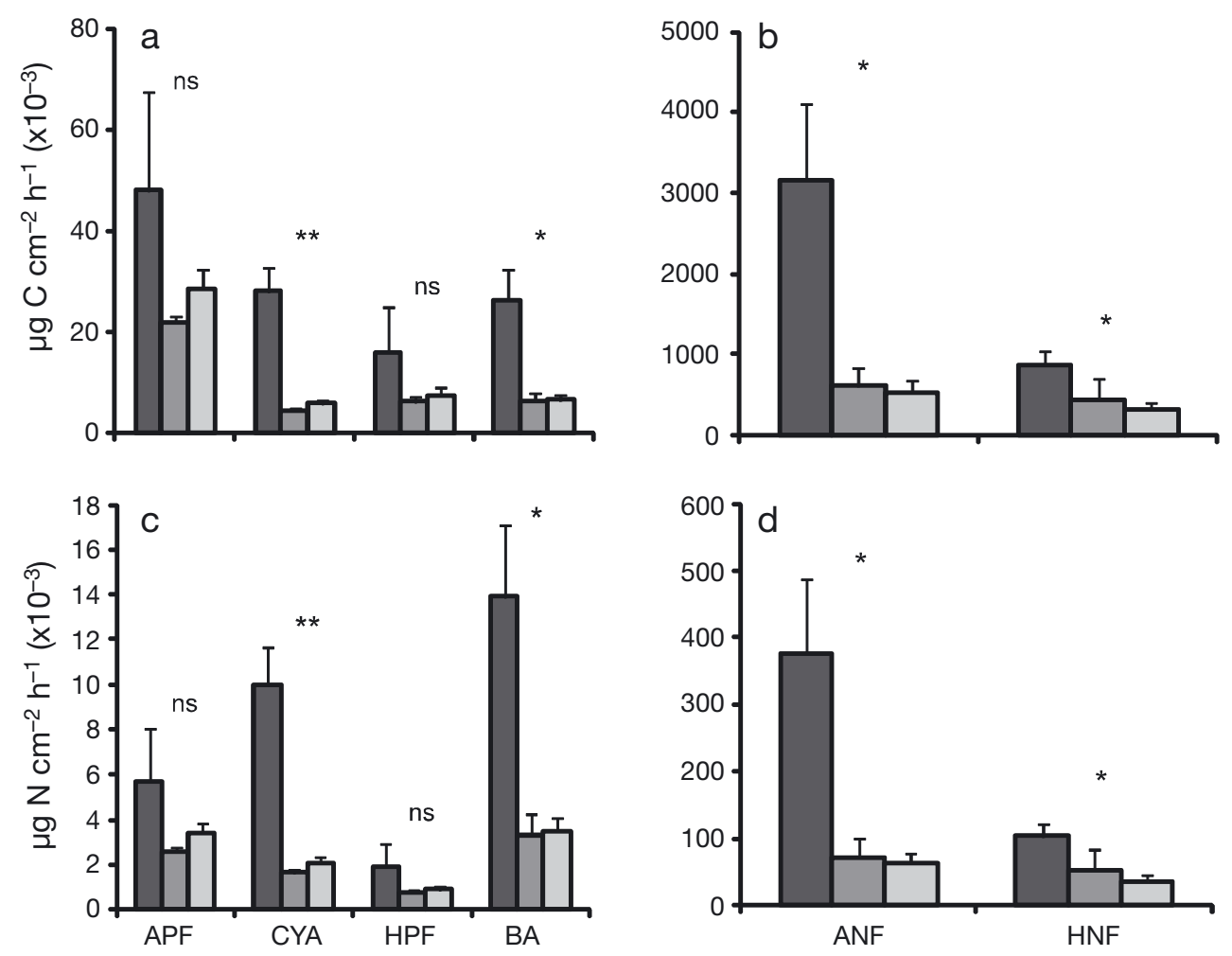

\section{Type of prey}

Fig. 4. Grazing rates expressed as $(\mathrm{a}, \mathrm{b})$ carbon $(\mathrm{C})$ and $(\mathrm{c}, \mathrm{d})$ nitrogen $(\mathrm{N})$ content normalized per $\mathrm{cm}^{2}$ per hour for Cladocora caespitosa (dark grey bar), Oculina patagonica (grey bar), and Turbinaria reniformis (light grey bar) according to the type of prey (means $\pm \mathrm{SE}, \mathrm{n}=9$ ). See Fig. 1 legend for abbreviations. For the Kruskal-Wallis test: ${ }^{*} \mathrm{p}<0.05,{ }^{* *} \mathrm{p}<0.001$, and ns: not significant

Table 3. Cladocora caespitosa, Oculina patagonica and Turbinaria reniformis. Total grazing rates (means \pm SE, $\mathrm{n}=9$ ) on pico- and nanoplankton for the 3 coral species and the results of the Kruskal-Wallis test $(p, H)$. These results take into account the grazing rates on bacteria, cyanobacteria and flagellates

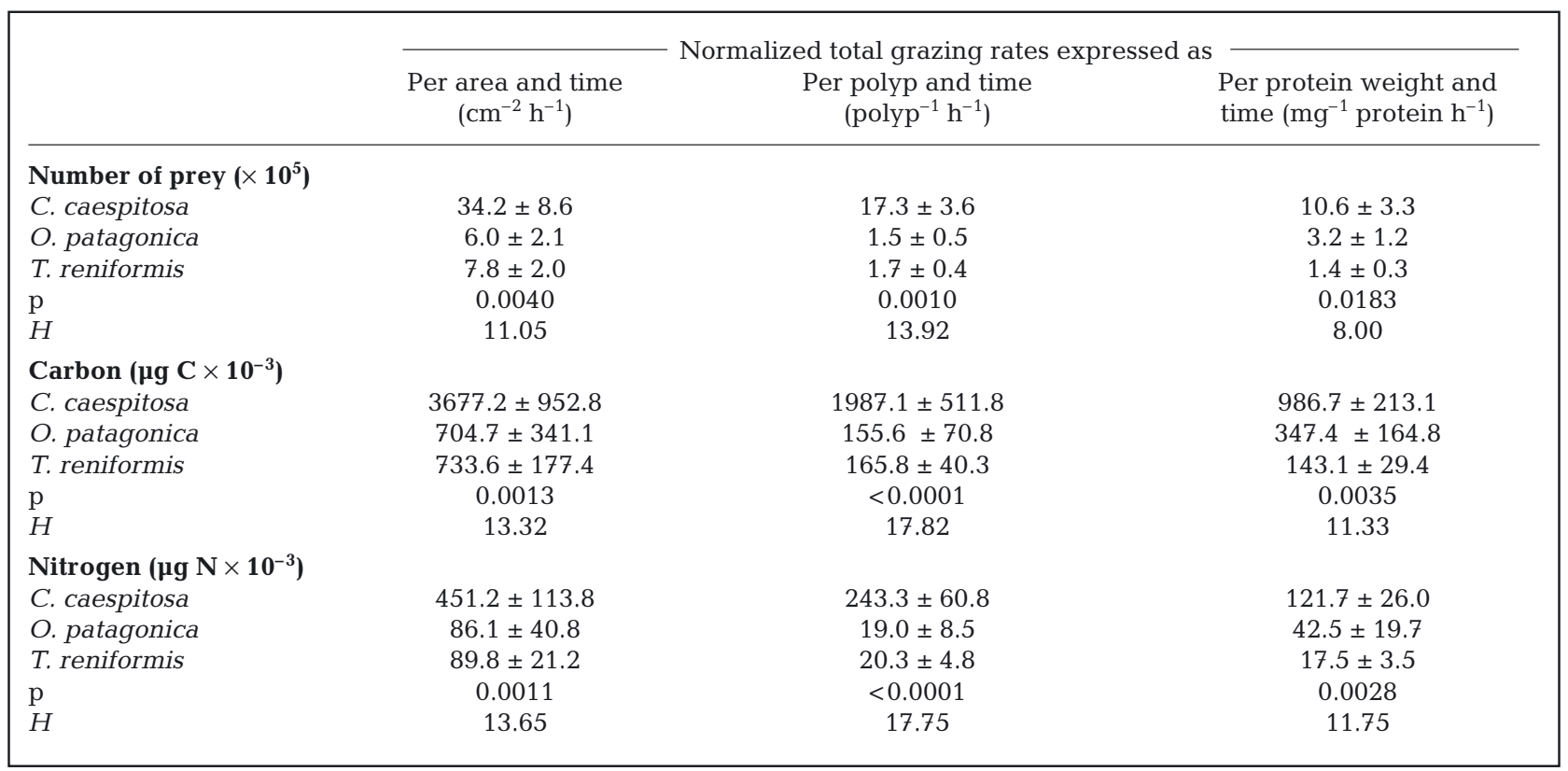


Table 4. Cladocora caespitosa, Oculina patagonica and Turbinaria reniformis. Maximum grazing rates $(\mathrm{means} \pm \mathrm{SE} ; \mathrm{n}=6)$ on microzooplankton (Artemia salina nauplii) for the 3 coral species and results of the Kruskal-Wallis test $(\mathrm{p}, H)$

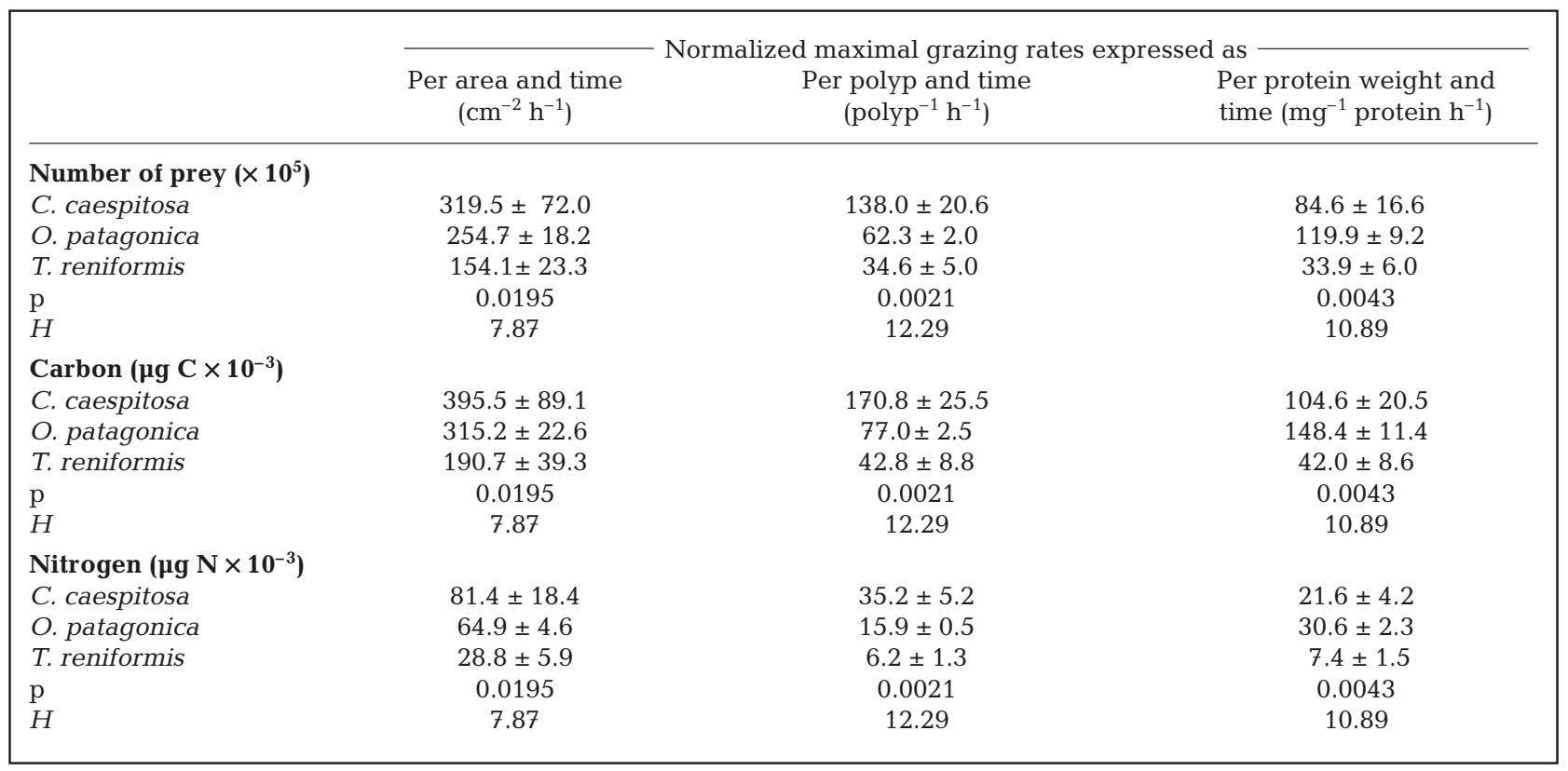

(Fig. 1), the daily heterotrophic carbon input $\left(H_{\mathrm{C}}\right)$ for the 3 coral species was $88.3 \pm 22.9,16.9 \pm 8.2$, and $17.6 \pm 4.3 \mu \mathrm{g} \mathrm{C} \mathrm{cm}^{-2} \mathrm{~d}^{-1}$ for C. caespitosa, O. patagonica, and T. reniformis, respectively. The corresponding $\mathrm{CHAR}$, i.e. the relative contribution of this type of food to daily maintenance costs, was 119.8, 28.7, and $15.9 \%$, respectively. The daily heterotrophic nitrogen input was 8 times lower than the carbon input.

\section{Microzooplankton}

The concentration of copepods and copepodites around the coral colonies in situ was $40 \pm 5$ ind. $\mathrm{l}^{-1}$. Table 4 shows the maximal grazing rates (after $30 \mathrm{~min}$ ) of Artemia salina nauplii for the 3 coral species, with an initial concentration of ca. 1700 nauplii $\mathrm{l}^{-1}$. Here again, Cladocora caespitosa was the species that ingested the greatest amount of prey (Table 4; Kruskal-Wallis: $\mathrm{p}<0.05$ ) compared to the 2 other species (Conover-Inman test: $\mathrm{p}<0.05$ ), except when grazing rates were expressed as prey $\mathrm{cm}^{-2} \mathrm{~h}^{-1}$. Using this normalization, grazing rates were equivalent for $C$. caespitosa and Oculina patagonica (Conover-Inman test: $\mathrm{p}>0.05$ ). Also, O. patagonica had higher grazing rates than Turbinaria reniformis (Conover-Inman test: $\mathrm{p}<0.05)$. Grazing rates of $C$. caespitosa were proportional to the prey concentration in seawater (Fig. 5). From the regression obtained, and using a mean natural zooplankton concentration of $40 \pm 5$ organisms $\mathrm{l}^{-1}$, the estimated in situ grazing rate is equal to 12.7 ind. polyp $^{-1} \mathrm{~h}^{-1}$ or $15.7 \mu \mathrm{g} \mathrm{C}$ polyp $\mathrm{p}^{-1} \mathrm{~h}^{-1}\left(32.6 \mu \mathrm{g} \mathrm{C} \mathrm{cm}^{-2} \mathrm{~h}^{-1}\right)$. Assuming this grazing rate and $1 \mathrm{~h}$ of feeding activity per day (see 'Materials and methods'), the daily heterotrophic carbon input $\left(H_{\mathrm{C}}\right)$ of this microzooplankton would be $32.6 \mu \mathrm{g} \mathrm{C} \mathrm{cm} \mathrm{c}^{-2} \mathrm{~d}^{-1}$, giving a CHAR estimation of $44.2 \%$. The nitrogen input was equal to about $6.7 \mu \mathrm{g}$ $\mathrm{N} \mathrm{cm}{ }^{-2} \mathrm{~d}^{-1}$. The microzooplankton CHAR would be almost the same for O. patagonica $(51.9 \%)$, considering that it ingests approximately 2 times less microzooplankton per polyp (Table 4) but has twice the number

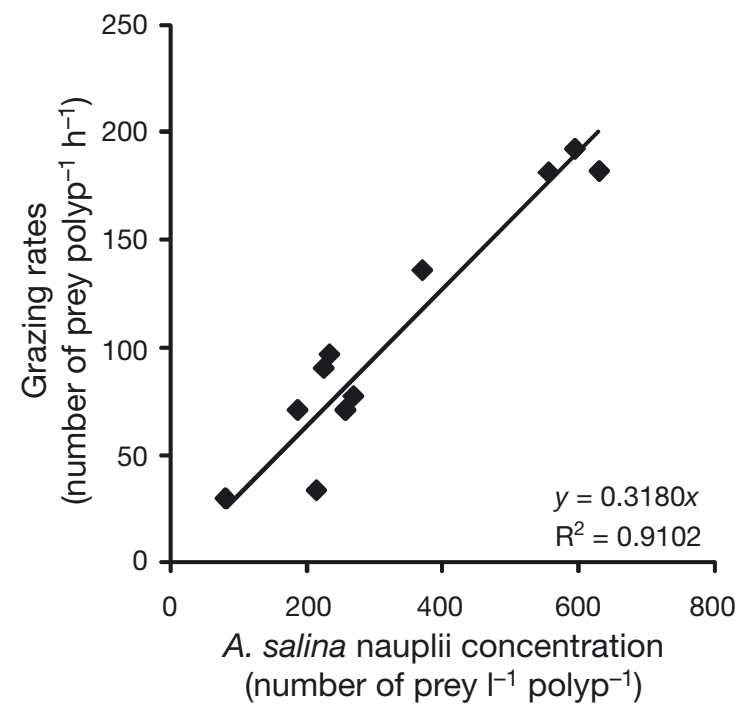

Fig. 5. Cladocora caespitosa. Grazing rate versus concentration of Artemia salina nauplii in seawater $(n=11)$ 
of polyps per $\mathrm{cm}^{2}$ (Table 1) than does C. caespitosa. For T. reniformis, the CHAR of microzooplankton would be negligible, because of the low in situ concentrations of reef zooplankton ( 2 organisms $\mathrm{l}^{-1}$ ) and lower predation rates compared to $C$. caespitosa.

\section{DPOM}

The carbon and nitrogen uptake rates via DPOM contained in the sediment for Cladocora caespitosa (Fig. 6) were positively correlated to the concentrations of DPOM in the surrounding seawater. The real DPOM concentration around the colonies of $C$. caespitosa in situ is unknown, and depends on the re-suspension rates of the sediment with waves and wind, or on the river discharge rate. However, if we assume one of the lowest grazing rates of DPOM obtained in this experimental study, and $1 \mathrm{~h}$ of feeding activity per day, then the daily carbon input would be equal to $10.0 \mu \mathrm{g} \mathrm{C}$ $\mathrm{cm}^{-2} \mathrm{~d}^{-1}$, giving a CHAR value of $13.6 \%$. This corresponds to a nitrogen input of 0.2 to $0.5 \mu \mathrm{g} \mathrm{N} \mathrm{cm}^{-2} \mathrm{~d}^{-1}$.

\section{DISCUSSION}

The aim of the present study was to understand the role of pico-, nano-, and microzooplankton, as well as detritus, in the diet of 3 scleractinian corals, 2 of Mediterranean origin and 1 of tropical origin, and compare temperate versus tropical symbiosis. Another aim was to determine how the temperate coral Cladocora caespitosa survives in a turbid environment and very low light levels in winter and which food source, among the locally abundant ones, is used by the coral to sustain its metabolism. The importance of heterotrophy to the overall carbon and nitrogen budget of C. caespitosa was therefore assessed. Collectively, the results obtained suggest that the temperate symbiotic coral $C$. caespitosa has a greater capacity for heterotrophy than tropical corals, with higher grazing rates on all sorts of food sources, from POM contained in the muddy sediment to pico-, nano-, and microzooplankton. This coral species has therefore the same feeding strategy as other benthic suspension feeders, such as asymbiotic gorgonians (Coma et al. 1994, Ribes et al. 2003). Picoand nanoplankton can provide most of the respiratory requirements of $C$. caespitosa, but the high in situ microzooplankton concentrations around coral colonies can also be a significant food supply.

The importance of microbial organisms, which are the main contributors to planktonic communities in terms of biomass and production (Stockner \& Antia 1986, Burkill et al. 1993), to the diet of benthic suspension-feeders and scleractinian corals in particular has
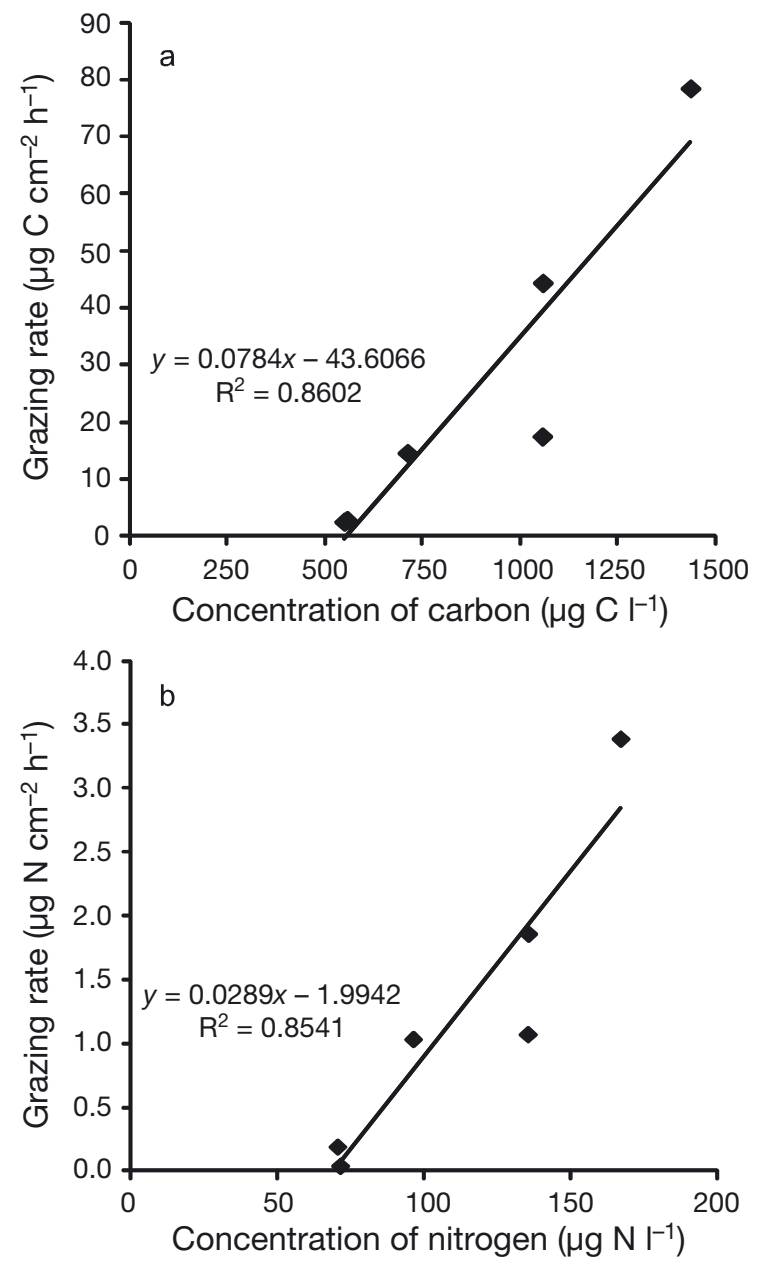

Fig. 6. Cladocora caespitosa. Grazing rates on particulate organic (a) carbon (C) and (b) nitrogen (N) normalized per $\mathrm{cm}^{2}$ per hour versus concentration in seawater $(n=6)$

already been demonstrated (Ribes et al. 2003, Houlbrèque et al. 2004). However, the present study is one of the first to compare the pico- and nanoplankton contribution to the carbon budget of temperate versus tropical species, using concentrations comparable to those measured in the waters of La Spezia or in tropical reef waters (Ferrier-Pagès \& Gattuso 1998). Although the 3 coral species were able to feed on pico- and nanoplankton, as previously observed for other scleractinian species (DiSalvo 1972, Farrant et al. 1987, Sorokin 1991, Ferrier-Pagès \& Gattuso 1998, Houlbrèque et al. 2004), grazing rates were at least 3 times higher for Cladocora caespitosa than for the other 2 species investigated. Since grazing rates of Oculina patagonica and Turbinaria reniformis fall into the range of rates measured for other symbiotic tropical corals (Houlbrèque et al. 2004), C. caespitosa has particularly high grazing rates for a symbiotic coral species. This special capacity to prey on minute cells can 
be related to the size of its polyp, or more likely to the feeding effort involved in the capture of such prey (Palardy et al. 2005). Among pico- and nanoplankton cells, nanoflagellates were the preferential prey items ingested by the 3 coral species, as previously observed (Ribes et al. 2003, Houlbrèque et al. 2004). They represented the largest contribution to the carbon and nitrogen ingested, due to their large size compared to the other pico- and nanoplankton cells.

Considering that the corals can continuously feed on this type of food (continuously present in high concentrations around the corals), the estimated daily carbon input for Cladocora caespitosa was $88.3 \pm 22.9 \mu \mathrm{g} \mathrm{C}$ $\mathrm{cm}^{-2} \mathrm{~d}^{-1}$, corresponding to more than half of the carbon provided daily by photosynthesis $(61.7 \%)$, under a light level of $50 \mu \mathrm{mol}$ photons $\mathrm{m}^{-2} \mathrm{~s}^{-1}$. The corresponding CHAR reached $100 \%$, suggesting that this type of food can sustain the respiratory requirements of the coral. Pico- and nanoplankton removal might explain how C. caespitosa can survive, grow, and maintain a significant density of viable zooxanthellae for $>50 \mathrm{~d}$ in complete darkness without a macrofood supply, as observed in Hoogenboom et al. (2010). Compared to $C$. caespitosa, minute organisms contributed respectively 3 and 10 times less to the carbon budget of the other coral species, Oculina patagonica and Turbinaria reniformis (CHAR of $28.7 \%$ and $15.9 \%$ ). However, these minute cells can still be an important supply of nitrogen and other nutrients to the symbiosis (Houlbrèque $\&$ Ferrier-Pagès 2009). Indeed, pico- and nanoplankton provided ca. $0.45,0.08$, and $0.09 \mu \mathrm{g} \mathrm{N} \mathrm{cm}{ }^{-1} \mathrm{~h}^{-1}$ to $C$. caespitosa, O. patagonica, and T. reniformis, respectively. This heterotrophic nitrogen input can be compared to the autotrophic input, by considering the uptake of inorganic nitrogen by zooxanthellae, which can be obtained from previous studies made on the tropical coral Stylophora pistillata (Grover et al. 2002, 2003). At concentrations of $1 \mathrm{\mu M} \mathrm{NH}_{4}{ }^{+}$, the zooxanthellae uptake rate was $0.12 \mu \mathrm{g} \mathrm{N} \mathrm{cm}{ }^{-1} \mathrm{~h}^{-1}$. According to these data, and assuming that the zooxanthellae of our studied corals supply the same amount of nitrogen, pico- and nanoplankton provide 5 times more (for $C$. Caespitosa) or as much nitrogen (for O. patagonica and T. reniformis) than the autotrophic pathway.

In addition to pico- and nanoplankton intake, Cladocora caespitosa was also able to derive a significant part of its carbon needs from the grazing of microzooplankton and DPOM. Grazing rates were proportional to the Artemia salina nauplii concentration in the surrounding water, indicating that this species is able to take full advantage of episodes of temporarily high prey availability to feed intensively, as observed in other Mediterranean suspension-feeders (Coma et al. 1994). It therefore has the typical Type I functional response of suspension-feeders (Valiela 1995). A high concentration of 30 to 50 copepods $\mathrm{l}^{-1}$ (adult and larvae) has been measured near the corals in situ. Assuming only $1 \mathrm{~h}$ of feeding per day, this type of food brings $32.6 \mu \mathrm{g} \mathrm{C} \mathrm{cm}^{-2} \mathrm{~d}^{-1}$, and represents $22.8 \%$ of the daily carbon supplied by photosynthesis. It also represents a huge supply of nitrogen (ca. $6.7 \mu \mathrm{g} \mathrm{N} \mathrm{cm} \mathrm{N}^{-2} \mathrm{~d}^{-1}$ ) compared to the other food sources, including uptake of inorganic nitrogen by the zooxanthellae. For the other coral species, microzooplankton can be an important source of carbon and nitrogen for Oculina patagonica, if concentrations are as high as those measured in the Gulf of La Spezia, near C. caespitosa. However, this point remains to be confirmed by in situ measurements of zooplankton concentrations, especially in the south of the Mediterranean Sea, where O. patagonica is common. Also, the amount of zooplankton available for tropical species like Turbinaria reniformis is not yet well defined and more studies are needed to assess the importance of this type of food in the carbon budget of these organisms.

Finally, it is difficult to assess the amount of carbon provided to Cladocora caespitosa by the detrital particulate organic carbon (POC) contained in the surrounding sediment, because we don't know at which rate and which amount of sediment is re-suspended around the colonies. Its nutritive value is also mainly a function of its origin (Tenore et al. 1982). In contrast to previous observations that organic detritus can be an excellent food source for benthic invertebrates, including gorgonians (Coma et al. 1994, Ribes et al. 2003) and sponges (Ribes et al. 1999), in the present study DPOM did not constitute a large input of carbon or nitrogen compared to pico-, nano-, and microzooplankton. However, it remains a significant source when the others are not available. Indeed, plankton concentrations are highly variable with the season, and are particularly low during the summer period, when the water column is highly stratified and does not allow the deep and nutrient-enriched waters to reach the surface. During this period of nutrient shortage, it has been shown that gorgonians, for example, suffer from starvation (Coma et al. 1994). Detrital POC and particulate organic nitrogen (PON) can therefore be of importance at this time of year.

In conclusion, the diet of Cladocora caespitosa is highly heterogeneous, including live $(0.2$ to $200 \mu \mathrm{m}$ in size) and detrital organic carbon, and demonstrates the important trophic ability of this coral. Even though this species accounts for a small fraction of the total community biomass in most Mediterranean coastal areas, it can form dense populations in some locations, such as Croatia or the Gulf of La Spezia. In this case, it may play a significant role in energy transfer from plankton to the benthos. One interesting conclusion from these results is that $C$. caespitosa appears to be able to sur- 
vive via heterotrophy alone, as has also been observed for temperate symbiotic sea anemones (Verde \& McCloskey 1996, Davy et al. 1997, Muller-Parker \& Davy 2001). This capacity seems to be a feature of temperate species and raises questions about the role of zooxanthellae under low light conditions.

Acknowledgments. We thank M. Abbate for copepod counts, N. Leblond for CHN analysis, C. Rottier and N. Tolstoï for laboratory assistance, and D. Allemand for support. Funding for this project was provided by the Centre Scientifique de Monaco and the Natural Sciences and Engineering Research Council of Canada (grant \# ES D3 - 378797 - 2009).

\section{LITERATURE CITED}

Anthony KRN, Fabricius KE (2000) Shifting roles of heterotrophy and autotrophy in coral energy budgets at variable turbidity. J Exp Mar Biol Ecol 252:221-253

Burkill PH, Edwards ES, John AWG, Sleigh MA (1993) Microzooplankton and their herbivorous activity in the northeastern Atlantic Ocean. Deep-Sea Res II 40:479-493

Coma R, Gili JM, Zabala M, Riera T (1994) Feeding and prey capture cycles in the aposymbiotic gorgonian Paramuricea clavata. Mar Ecol Prog Ser 115:257-270

Cupido R, Cocito S, Barsanti M, Sgorbini S, Peirano A, Santangelo G (2009) Unexpected long-term population dynamics in a canopy-forming gorgonian coral following mass mortality. Mar Ecol Prog Ser 394:195-200

Davies PS (1984) The role of zooxanthellae in the nutritional energy requirements of Pocillopora eydouxi. Coral Reefs 2:181-186

Davy SK, Lucas IAN, Turner JR (1996) Carbon budgets in temperate anthozoan-dinoflagellate symbioses. Mar Biol 108:137-144

Davy SK, Lucas IAN, Turner JR (1997) Uptake and persistence of homologous and heterologous zooxanthellae in the temperate sea anemone Cereus pedunculatus. Biol Bull (Woods Hole) 192:208-216

Dimond J, Carrington E (2007) Temporal variation in the symbiosis and growth of the temperate scleractinian coral Astrangia poculata. Mar Ecol Prog Ser 348:161-172

DiSalvo LH (1972) Bacterial counts in surface open waters of Eniwetok Atoll, Marshall Islands. Atoll Res Bull 151:1-5

Falkowski PG, Dubinsky Z, Muscatine L, Porter JW (1984) Light and the bioenergetics of a symbiotic coral. Bioscience 34:705-709

Falkowski PG, Dubinsky Z, Muscatine L, McCloskey L (1993) Population control in symbiotic corals. Bioscience 43: 606-611

Farrant PA, Borowitzka MA, Hinde R, King RJ (1987) Nutrition of the temperate Australian coral Capnella gaboensis. Mar Biol 95:575-581

Ferrier-Pagès C, Gattuso JP (1998) Biomass, production and grazing rates of pico and nanoplankton in coral reef waters (Miyako Island, Japan). Microb Ecol 35:48-57

Ferrier-Pagès C, Gattuso JP, Cauwet G, Jaubert J, Allemand D (1998) Release of dissolved organic carbon and nitrogen by the zooxanthellate coral Galaxa fascicularis. PSZN I: Mar Ecol 172:265-274

Ferrier-Pagès C, Witting J, Tambutté E, Sebens KP (2003) Effect of natural zooplankton feeding on the tissue and skeletal growth of the scleractinian coral Stylophora pistillata. Coral Reefs 22:229-240

FitzGerald LM, Szmant AM (1988) Amino acid metabolism: adaptations to low nutrient conditions? Proc 6th Int Coral Reef Symp, Townsville 3:5-9

Frost BW (1972) Effects of size and concentration of food particles on the feeding behavior of the marine planktonic copepod Calanus pacificus. Limnol Oceanogr 17:805-815

Grottoli AG, Rodrigues LJ, Palardy JE (2006) Heterotrophic plasticity and resilience in bleached corals. Nature 440: 1186-1189

Grover R, Maguer JF, Reynaud-Vaganay S, Ferrier-Pagès C (2002) Uptake of ammonium by the scleractinian coral Stylophora pistillata: effect of feeding, light, and ammonium concentrations. Limnol Oceanogr 47:782-790

> Grover R, Maguer JF, Allemand D, Ferrier-Pagès C (2003) Nitrate uptake in the scleractinian coral Stylophora pistillata. Limnol Oceanogr 48:2266-2274

> Hoogenboom M, Rodolfo-Metalpa R, Ferrier-Pagès C (2010) Co-variation between autotrophy and heterotrophy in the Mediterranean coral Cladocora caespitosa. J Exp Biol 213: 2399-2409

> Houlbrèque F, Ferrier-Pagès C (2009) Heterotrophy in tropical scleractinian corals. Biol Rev Camb Philos Soc 84:1-17

Houlbrèque F, Tambutté E, Richard C, Ferrier-Pagès C (2004) Importance of a micro-diet for scleractinian corals. Mar Ecol Prog Ser 282:151-160

- Levy O, Mizrahi L, Chadwick-Furman NE, Achituv Y (2001) Factors controlling the expansion behaviour of Favia favus (Cnidaria: Scleractinia). Effects of light, flow and planktonic prey. Biol Bull (Woods Hole) 200:118-126

> Marsh JA (1970) Primary productivity of reef-building calcareous and red algae. Ecology 51:255-263

- McCloskey LR, Muscatine L (1984) Production and respiration in the Red Sea coral Stylophora pistillata as a function of depth. Proc R Soc Lond B 222:215-230

Miller MW (1995) Growth of a temperate coral: effects of temperature, light, depth, and heterotrophy. Mar Ecol Prog Ser 122:217-225

- Muller-Parker G, Davy SK (2001) Temperate and tropical algal-sea anemone symbioses. Invertebr Biol 120:104-123

> Muscatine L, McCloskey LR, Marian RE (1981) Estimating the daily contribution of carbon from zooxanthellae to coral animal respiration. Limnol Oceanogr 26:601-611

Palardy JE, Grottoli AG, Matthews KA (2005) Effects of upwelling, depth, morphology and polyp size on feeding in three species of Panamian corals. Mar Ecol Prog Ser 300:79-89

Peirano A (2007) In vivo measurements of the seasonal photosynthetic fluorescence of the Mediterranean coral Cladocora caespitosa (L.). Sci Mar 61:629-635

Peirano A, Morri C, Mastronuzzi G, Bianchi CN (1998) The coral Cladocora caespitosa (Anthozoa, Scleractinia) as a bioherm builder in the Mediterranean Sea. Mem Descr Carta Geol Ital 52:59-74

> Peirano A, Morri C, Bianchi CN (1999) Skeleton growth and density pattern of the temperate, zooxanthellate scleractinian Cladocora caespitosa from the Ligurian Sea (NW Mediterranean). Mar Ecol Prog Ser 185:195-201

Peirano A, Abbate M, Cerrati G, Difesca V, Peroni C, RodolfoMetalpa R (2005) Monthly variations in calyx growth, polyp tissue, and density banding of the Mediterranean scleractinian Cladocora caespitosa (L.). Coral Reefs 24: 404-409

Picciano M, Ferrier-Pagès C (2007) Grazing of pico- and nanoplankton by the Mediterranean red coral Corallium rubrum. Mar Biol 150:773-778

Piniak GA (2002) Effects of symbiotic status, flow speed, and prey type on prey capture by the facultatively symbiotic temperate coral Oculina arbuscula. Mar Biol 141:449-455

> Porter KG, Feig YS (1980) The use of DAPI for identifying and counting aquatic microflora. Limnol Oceanogr 25:943-948 
Ribes M, Coma R, Gili JM (1998) Heterotrophic feeding by gorgonian corals with symbiotic zooxanthella. Limnol Oceanogr 43:1170-1179

Ribes M, Coma R, Gili JM (1999) Natural diet and grazing rate of the temperate sponge Dysidea avara (Desmospongiae, Dendroceratida) throughout the annual cycle. Mar Ecol Prog Ser 176:179-190

Ribes M, Coma R, Rossi S (2003) Natural feeding of the temperate asymbiotic octocoral gorgonian Leptogorgia sarmentosa (Cnidaria: Octocorallia). Mar Ecol Prog Ser 254: $141-150$

Rodolfo-Metalpa R, Richard C, Allemand D, Bianchi CN, Morri C, Ferrier-Pagès C (2006) Response of zooxanthellae in symbiosis with the Mediterranean corals Cladocora caespitosa and Oculina patagonica to elevated temperatures. Mar Biol 150:45-55

Rodolfo-Metalpa R, Peirano A, Houlbrèque F, Abbate M, Ferrier-Pagès $C$ (2008) Effects of temperature, light and heterotrophy on the growth rate and budding of the temperate coral Cladocora caespitosa. Coral Reefs 27:17-25

Rossi S, Ribes M, Coma R, Gili JM (2004) Temporal variability in zooplankton prey capture rate of the passive suspension feeder Leptogorgia sarmentosa (Cnidaria: Octocorallia), a case study. Mar Biol 144:89-99

Sebens KP, Vandersall KS, Savina LA, Graham KR (1996) Zooplankton capture by two scleractinian corals Madracis mirabilis and Montastrea cavernosa in a field enclosure. Mar Biol 127:303-317

Sheldon RW, Rassoulzadegan F (1987) A method for measuring plankton production by particle counting. Mar Microb Food Webs 2:29-44

Editorial responsibility: Peter Edmunds, Northridge, California, USA
Smith PK, Khrohn RI, Hermanson GT, Malia AK and others (1985) Measurement of protein using bicinchoninic acid. Anal Biochem 150:76-85

Sorokin YU (1991) Biomass, metabolic rates and feeding of some common reef Zoantharians and Octocorals. Aust J Mar Freshw Res 42:729-741

Stockner JG, Antia NJ (1986) Algal picoplankton from marine and freshwater ecosystems: a multidisciplinary perspective. Can J Fish Aquat Sci 43:2472-2503

Szmant-Froelich A, Pilson ME (1984) Effect of feeding frequency and symbiosis with zooxanthellae on nitrogen metabolism and respiration of the coral Astrangia danae. Mar Biol 81:153-162

Tenore KR, Cammen L, Finlay SEG, Philippe N (1982) Perspective of research on detritus: do factors controlling the availability of detritus to macroconsumers depend on the source? J Mar Res 40:473-490

Trager GC, Hwang JS, Strickler JR (1990) Barnacle suspension-feeding in variable flow. Mar Biol 105:117-127

Valiela I (1995) Marine ecological processes. Springer, New York, NY

Verde EA, McCloskey LR (1996) Photosynthesis and respiration of two species of algal symbionts in the anemone Anthopleura elegantissima (Brandt) (Cnidaria; Anthozoa). J Exp Mar Biol Ecol 195:187-202

Yahel R, Yahel G, Genin A (2005) Near-bottom depletion of zooplankton over coral reefs: I: diurnal dynamics and size distribution. Coral Reefs 24:75-85

Zibrowius H (1980) Les scléractiniaires de la Méditerranée et de l'Atlantique nord-oriental. Mem Inst Oceanogr Monaco 11:1-284

Submitted: June 7, 2010; Accepted: October 26, 2010 Proofs received from author(s): January 14, 2011 